\title{
GAAL GYÖRGY*
}

\section{GÁL KELEMEN, A SZERKESZTŐ}

\author{
Kulcsszavak: Gál Kelemen, Kolozsvár, Unitárius Kollégium, értesítők, Keresztény Magvető
}

A 20. század első évtizedeinek egyik legjelentősebb és legismertebb erdélyi tanáregyénisége volt Gál Kelemen (1869-1945). A kolozsvári Unitárius Kollégiumban érettségizik, majd Kolozsvárt és Grazban végzi egyetemi tanulmányait. 1892-ben német-latin szakos tanári diplomát, 1895-ben filozófiai doktorátust szerez. 1891-től 1931-ig az Unitárius Kollégium tanára, közben 1900-tól 1925-ig igazgatója is. Országos elismerést szerez tanintézetének. Emellett filozófiai és pedagógiai írásaival, egyháztörténeti kutatásaival tűnik ki. Főműve az Unitárius Kollégium kétkötetes, több mint ezerlapos története.

A múlt századfordulón jóformán minden bölcsész - szükség esetén - szerkesztői munkát is tudott végezni. A havonta megjelenő felekezeti vagy tudományos folyóiratokat is rendszerint egy-két szerkesztő állította össze, többnyire mellékfoglalkozásként. Gál Kelemen alapfoglalkozását tekintve tanár volt, de szerkesztői munkája is számottevő. Évtizedekben mérhető a szerkesztésében megjelenő kiadványok időfutama.

Első alkalommal Boros György teológiai tanár, a Dávid Ferenc Egylet alapítója és havi folyóiratának szerkesztője kéri fel két fiatal kollégáját, Gál Kelement és Gálfi Lőrincet, hogy amerikai útja idején helyette szerkesszék az Unitárius Közlönyt. Boros 1900 szeptemberében tér vissza - a Harvard Egyetem tiszteletbeli doktorátusával kitüntetve - az amerikai egyházi kiküldetésből. A szeptemberi számban jelzi, hogy négy hónapi távollét után átveszi a szerkesztést, s „legszívesebb köszönetét” nyilvánítja az őt átmenetileg helyettesítő két kollégájának. ${ }^{1}$ Úgyhogy a május és augusztus között megjelent számok szerkesztése hárulhatott a két tanárra. A négy szám természetesen folytatta a kijelölt utat és hagyományokat. Különösen nehéz lehetett az augusztusi számot megszerkeszteni: a főszerkesztő öccse, Boros Sándor kollégiumigazgató hirtelen halálát követően ez emlékszámmá kerekedik. Első oldalán gyászkeretben közlik Boros arcképét, majd részletes életrajza, a temetés leírása és az elhangzott beszédek szövege következik. A másik hosszabb írás éppen Boros György beszámolója amerikai útja addigi eseményeiről.

Az igazgatósággal szerkesztői feladat is hárult Gál Kelemen vállaira. Ugyanis évről évre össze kellett állítania tanintézete értesítőit. Az értesítők szerkesztését és közzétevését az 1850/51-es tanévtől bevezetett osztrák tanügyi rendelet, az Organisations-Entwurf írta elő, de többnyire csak a római katolikus tanintézetek engedelmeskedtek e téren. Az unitáriusok

* GaAL György (1948), dr., magyar irodalom- és mûvelődéstörténész.

1 Boros György: A szerkesztó szava. Unitárius Közlöny XIII(1900). 267-268. 
nem is tulajdonítottak túlzott jelentőséget az értesítőknek, hiszen a kis egyház három iskolájának az eseményei az Egyházi Képviselő-tanács ülésein és az évi főtanácsi ülésen is megbeszélésre kerültek, s így hamar közismertté váltak. Mikor az első unitárius értesítő megjelent, már kikristályosodott szerkezeti felépítést követhetett. Rendszerint egy „programértekezés” került a füzet élére, ez lehetett akár doktori értekezés vagy székfoglaló beszéd, esetleg nekrológ, útleírás. Egy fejezet az elmúlt tanév fontosabb eseményeit vette számba, majd a tanári kar névsora a tanított tárgyakkal és besorolással, valamint a diákság - legtöbbször táblázatba foglalt - osztályonkénti névsora következett. Az alapfejezetekhez még számos jelentés, kimutatás, beszámoló csatlakozhatott. Az igazgatón múlott, hogy miként rendezte a fejezeteket, hogyan érzékeltette az iskola felépítését, felekezeti jellegét.

Az unitáriusok első ilyen kiadványa az „Értesítő az Unitárius Vallásközönség iskoláiról az 1879-80-ik tanévben” címmel jelent meg 78 lapon Kovács János igazgató-tanár szerkesztésében². Ebben a első fejezet a kolozsvári „főtanodáról”, a második a tordai, a harmadik a székelykeresztúri „középtanodákról” szólt. Kovács tizenkét esztendeig szerkesztette ezt a közös értesítőt. Először bevezető értekezést csak a IX. évfolyamban közölnek Brassaitól (Tudtak-e a középkoriak latinul?). 1891-től Ulár Pál veszi át a szerkesztést, majd 1893-tól Boros Sándor. Mindegyikük valamennyit módosít a szerkezeten. A legfontosabb változás, hogy 1893-tól a székelykeresztúriak önállósítják a maguk értesítőjét, 1894-től pedig a tordaiak is. Úgyhogy csak A kolozsvári Unitárius Főiskola szerepel a címlapon, majd ezt még Boros módosítja az 1896/97-es tanévtől így: A kolozsvári Unitárius Kollégium (Papnevelő Intézet, Államilag segélyezett Főgimnázium és Elemi Iskola) Értesítője az 1896-97-ik tanévről.

Gál Kelemen negyedszázados igazgatósága az értesítők történetében is külön fejezetet jelent. Borosról állapítja meg: „évről évre nagyobb gonddal” szerkesztette az értesítőket. Ez rá is jellemző, sőt ő már szinte tökéletesekké tette azokat. Az első szerkesztésében megjelent kötetben ${ }^{3}$, mely már a XXII. évfolyamjelzést viseli és LXXVI+159, vagyis összesen 276 lap terjedelmű, közli Benczédi Gergely iskolatörténetét ${ }^{4} \mathrm{~s}$ három tanár életrajzát. A következő kötet, a maga 300 lapjával, 20 fényképmellékletével valóságos emlékkönyvvé bővül az új épület átadása alkalmából. Benne találjuk a kollégium építéstörténetét Gál Kelementől, a megnyitó ünnepség leírását az ott elhangzott beszédek szövegével, Pákei Lajos szakszerú leírását az épületről, Kiss Ernő tanár megemlékezését Bölöni Farkas Sándorról, a 132 paragrafusos Internátusi szabályzatot, s csak ezután következik a tulajdonképpeni adattár az iskolai évről.

1905/906-ra kristályosodik ki az az évkönyv-szerkezet, mely másfél évtizedre állandósul. Élén egy értekezés, megemlékezés áll. I. fejezete a kollégium szervezetét, felügyeletét, igazgatását mutatja be: eszerint három nagy egységhez (papnevelő, főgimnázium, elemi) közös létesítmények társulnak, mint az internátus, konviktus, könyvtár. A II. fejezet a Papnevelő Intézeté 11 alfejezetre tagolva, ezt az értesítő címlapján is megnevezett dékán szerkeszti. A III. fejezet a Főgimnáziumé 8-10 alfejezettel. Bevezeti a tanév története, mely kitér a tanévnyitásra, a tanári kar változásaira, tanulmányi, fegyelmi, valláserkölcsi ügyekre, egészségi állapot-

2 Részletesebb feldolgozása GaAl György: A kolozsvári Unitárius Kollégium értesitoói = Uő: Múzsák és erények jegyében. Unitárius Egyház, Kvár, 2001. 118-136.

3 A kolozsvári Unitárius Kollégium (Papnevelő Intézet, Főgimnázium és Elemi Iskola) Értesitöje az 1900-901. iskolai évről. Szerkesztette Dr. GáL Kelemen igazgató. XXIII(1902). Kvár.

4 A kolozsvári Unitárius Kollégium vázlatos története (1566-1900). I-LXXVI. 
ra, ünnepségekre, látogatásokra, alapítványokra, internátusra, konviktusra. Következnek a fontosabb rendeletek, átiratok, az igazgatóság múködése. Az oktatás alfejezet 8 alpontja a végzett tananyagról, dolgozattémákról, tantervről, érettségiről, valamint a diákok osztályonkénti és tárgyankénti előmeneteléről nyújt képet (a tanulók száma 330 körüli). Az öt szertár gyarapodása és az ifjúsági egyletek múködése is idetartozik. A IV. fejezet a kollégiumi nagykönyvtár adatait tartalmazza, a beérkezett 549 mú címét is, csak szám szerint utal a 189 iskolai értesítőre. További fejezetek a kórházzal, segélyezéssel (ösztöndíjak), elemi iskolával, a jövő tanévi beiratkozással és az érvényes tankönyvekkel foglalkoznak. A terjedelem az 1910-es évekre 210-220 lap körül állandósul.

1913/14-tő1 1921/22-ig három részre tagolódik mindegyik kötet: I. Papnevelő Intézet (1916-tól Teológiai Akadémia); II. Főgimnázium; III. Elemi Iskola ${ }^{5}$. Az eleinte túlméretezett terjedelem a világháború vége felé fokozatosan csökken, 1918/19-ben már 53 lapra zsugorodik, s a papír minősége is utal az ínséges időkre. A fehér sorhelyek a cenzúra működését jelzik. Több alfejezetnél csak a megjegyzés tudatja, hogy nincs említésre méltó, minden a régi. A tanulók minősítés szerint csoportosítva kerülnek felsorolásra (jelesek, jók, elégségesek stb.). A diáklétszám még mindig 330. Az 1919/20-as füzet szintén félszáz lapos, de már újságpapírra nyomják. A következő két évben sem áll be nagyobb változás. Időnként utalás történik arra, hogy az új hatalom beavatkozik az iskolai életbe. S természetesen négyévenként cserélődnek a társszerkesztő teológiai tanárok.

1922-ben kezdődnek a nagy változtatások. A román tanügyi hatóságok elrendelik, hogy az értesítőket csak románul lehessen megjelentetni, utóbb engedélyezik, hogy kétnyelvűek legyenek. Mivel a teológiára ez a rendelet nem vonatkozik, az önállósítja kiadványát. A teológiai értesítő folytatólagosan megjelenik a dékánok szerkesztésében 1944-ig. Az iskolai értesítő kiadása elé kettős akadály gördül: a kétnyelvűség megduplázza a terjedelmet, a fordítás elvégzésére sem könnyű belső embert találni. Így vált kolligátummá az 1922/23, 1923/24, 1924/25-re kiadott értesítő. Ezek mindegyike kétrészes: I. Főgimnázium, II. Elemi Iskola. Az egyes fejezetek a lehető legrövidebbre zsugorodnak, az évfolyamok terjedelme 50-60 lap közötti. A kétnyelvű cím így hangzik: Anuarul pe anii şcolari 1922-23, 1923-24, 1924-25 al Colegiului Unitar [!] din Cluj - A kolozsvári Unitárius Kollégium Értesítője az 1922-23, 1923-24, 1924-25. iskolai évekről. Szerkesztette dr. Gál Kelemen igazgató-tanár. Cluj-Kolozsvár, 1927. Mint látható, ezt a kolligátumot is csak két év késéssel tudták kinyomatni. Röviden esik szó benne a román tanügyi rendszer megkövetelte változtatásokról, visszásságokról. Megjelenik a IV. osztályos abszolválóvizsga lefolyása és eredménye. Külön alfejezetet kap az egyre szigorúbb bakkalaureátusi vizsga. A diáklétszám sorvadása jellemzi az állapotokat: az 1925-ben záruló tanévben a főgimnáziumba 207 tanuló (ebből 143 unitárius), az elemibe 42 járt.

Az értesítő az új igazgató, Borbély István szerkesztésében 1925-26-ra is megjelenik, de a következő két évre nem sikerül összeállítani, csak egyes fejezeteik készülnek el, s kéziratban a levéltárba kerülnek.

5 Az 1916/17-es cím: A kolozsvári Unitárius Kollégium (Teológiai Akadémia, Főgimnázium, Elemi Iskola) Értesitóje az 1916-17-ik iskolai évről. Szerkesztették: a teológiai részt GÁLFI Lőrinc dékán, a többit Dr. Gál Kelemen igazgató. XXXVIII(1917). Kvár. 
Gál Kelemen az értesítők szerkesztését tökélyre vitte, mindegyik füzet jóformán az unitárius egyház életének is egy fejezetét tükrözi ${ }^{6}$. Utóbb nyugodt szívvel lezárhatta kétkötetes kollégiumtörténetét 1900-zal, mert tudta, hogy igazgatásának negyed századáról tökéletes képet lehet kapni a kiadott értesítőkből. Az egyes programértekezések, életrajzok ugyanakkor igen gazdag anyagot halmoznak fel a művelődéstörténet számára is.

Az értesítőkkel párhuzamosan nyolc évig a kollégiumigazgató az unitáriusok legrégebbi és legrangosabb folyóiratának, a Keresztény Magvetőnek is szerkesztője volt. A Magvető története 1860-ig nyúlik vissza, megalapítását Nagy Lajos tanár javasolta, címét Kriza János, akkor városi lelkész ajánlotta ${ }^{7}$. Az első két kötetet $(1861,1863)$ ők szerkesztették fóleg teológiai jellegü évkönyvként. Tőlük Buzogány Áron tanár és Ferencz József lelkész veszi át a szerkesztést, s ők még két évkönyvet $(1867,1868)$ hoznak ki. 1870-től válik a kiadvány negyedévi folyóirattá, s egyben a művelődési, tanügyi, bölcseleti jelleget helyezik előtérbe a teológiaival szemben. Ekkor a fơvárosba távozó Buzogány helyett Kovácsi Antal latintanár válik társszerkesztővé. Rá főleg a tanügyi vonatkozások hárulnak, a szellemi irányító Ferencz József marad. 1874-ben Simén Domokos teológiai tanár lesz a társszerkesztő. Miután 1876 augusztusában Ferencz Józsefet püspökké választják, lelkészutóda, Péterfi Dénes veszi át a szellemi vezetést, s áttérnek az évi hat füzetre. Mellette 1878-ban bekövetkezett haláláig Simén Domokos, utána Kovács János történelemtanár és kollégiumigazgató a társszerkesztő, de közremúködése többnyire csak a tanügyi vonatkozásokra és az angol-amerikai kapcsolatok ápolására korlátozódik. Péterfi több mint három évtizedig szerkeszti a Keresztény Magvetőt, s országos jelentőségű liberális teológiai, művelődéstörténeti és bölcseleti folyóirattá teszi. 1896-ban maga mellé vesz három fiatal tanárt főmunkatársként, ezek Kanyaró Ferenc, Gál Kelemen és Gálfi Lőrinc. Velük tulajdonképpen a lap teljes spektrumát lefedte: az első történész, a második bölcsész, a harmadik klasszika-filológus és teológus volt. Kanyaró egyre súlyosbodó betegsége miatt legfeljebb írásaival tudott közremúködni, de Gál és Gálfi minden szempontból rászolgáltak a bizalomra. Gál a Nevelés- és oktatásügy rovatot egyszeriben fellendítette, gazdaggá tette. Német forrásokra alapozó filozófiai tanulmányai is új színnel gazdagították a folyóiratot. Iskolatörténeti anyagot és könyvismertetéseket is közölt.

1910 végén, teljes testi-szellemi erőben az 59 éves Péterfi Dénes bejelentette, hogy minden egyházi tisztségétől megválik, és nyugalomba vonul. A Magvető szerkesztését két tanítványára hagyta.

Utóbb Gál Kelemen - Péterfi halálakor - elismeréssel vallotta: „A Keresztény Magvetőnek kezdetben mint figyelmes olvasója, később mint belső munkatársa tanultam megismerni az ő minden részletre kiterjedő, figyelmes valóját és kritikai rostáló szellemét. Az a körülmény, hogy visszavonulásakor engem ajánlott utódjául, tiszteletre hangol, de nem tesz elfogulttá

6 Az Értesítők majd mindegyik füzetéről rövid ismertetés jelent meg a Keresztény Magrvetóben, néhányról az Unitárius Közlönyben is. A Főtanácsi jegyzőkönyvek már 1901-től szinte évente elismerésben részesítik Gált az „Értesítő gondos szerkesztéséért”.

7 A Keresztény Magvető története és könyvészete GaAL György: A, „zép, jó és igaz” Magvetöje. Százötven év az egyház és müvelódés szolgálatában. Erdélyi Unitárius Egyház, [Kvár], 2011 (Keresztény Magvető Füzetei 47). 
emlékezete iránt. A folyóirat a maga 57 évfolyamával ma már nem csak az unitárius egyház, hanem az egész magyar protestáns teológiai tudomány értéke és kincse, amelyet a tudományos kutatásnak mellőzni nem lehet. Beszél sajátmagáról, s arról a gondosságról, mellyel Péterfi szerkesztette, s szelleme bélyegét rányomta”. ${ }^{8}$

Az 1911-es évfolyam első oldalain a két új szerkesztő, Gál Kelemen és Gálfi Lőrinc az olvasó közönséghez fordul programadó és pártolást kérő levélben. Kifejtik: „Folyóiratunk jelen számával a 46. évébe lépett. Megfutott hosszú pályája alatt nemes törekvéssel szolgálta a szabadelvű kereszténység nagy céljait és a tiszta keresztény teizmus tudományos érdekeit. Új célokat a jövőre sem tűz maga elé, mert nem érzi, hogy régi céljait már megvalósította volna. Legfeljebb új eszközöket alkalmazhat célja megvalósítására, amelyeket a haladás, a kor eszméi, megváltozott gondolkodásmódja és módszerei önként ajánlanak és megkövetelnek. Az emberi lélek nagy kérdései voltak mindig a Keresztény Magvető vizsgálódásának tárgyai, és ezek mellett akarunk maradni a jövőben is. Ezért célunk szerint vallási, erkölcsi, társadalmi, nevelési és bölcsészeti kérdések megvitatására folyóiratunk bárki számára nyitva áll, s törekvésünk az lesz, hogy olvasóinknak ilyen tartalmú dolgozatokat nyújtsunk.

Széttagolt társadalmunkban az egységes megértés és elfogulatlan bírálat hívei akarunk maradni. Folyóiratunkat tradíciói az unitárius egyházhoz csatolják, de mint eddig nem tettük, úgy ezután sem szolgálunk dogmatikus felekezeti érdekeket, hanem inkább a tudományos meggyőződést, a szabad vizsgálódást, magát a valóságot, amennyire azt az emberi értelem megközelítheti”. ${ }^{9}$

A két szerkesztő igen nagy terhet vesz a nyakába, ha arra gondolunk, hogy Gál Kelemen ekkor már egy évtizede az Unitárius Kollégium igazgatója, Gálfi pedig a teológia újszövetségi tanszékének éppen megválasztott professzora, s nemsokára az akadémia dékánja is. $\mathrm{S}$ e terhek alig négy év múlva a világháború próbatételeivel is súlyosbodnak. A szerkesztés az elkövetkező években főleg Gál Kelemen vállán nyugodott. A szerkesztők érdeme, hogy a régi munkatársakat megtartva rendre bevonták a századfordulótól fellépő fiatalabb lelkész- és tanárnemzedéket is a munkatársi körbe.

Az új szerkesztők az eddigi kilencbeosztásos tartalomjegyzéket ${ }^{10}$ már 1911-tôl leegyszerüsítették. Ez logikus megoldásnak tekinthető, mert az év folyamán megjelent cikkek besorolása a tartalomjegyzékbe eléggé vitatható volt az utóbbi években. Egyes rovatok elkülönítése akár a fő laptestben, akár a függelékben (Egyházi élet/Vegyes tartalmúak/Aranykönyv/Különfélék) már fölöslegessé vált. Ugyhogy ezután három rovatba sorolták az írásokat: I. Önálló cikkek, tanulmányok; II. Irodalom; III. Vegyes közlemények/Különfélék.

Az első két rovatban a szerkesztő vonzódásának megfelelően túlsúlyba került a filozófia, pedagógia és az irodalomtörténet. Míg eddig főleg az angol-amerikai irányú érdeklődés jellemezte a Magvetőt, most - lehet a háborús viszonyok hatására is - hangsúlyozottabbá válik a német orientáció.

8 GáL Kelemen: Péterfi Dénes 1851. aug. 30.-1925. máj. 15. Unitárius Közlöny XXXV(1925).90-92.

9 Azolvasóközönséghez. XLVI(1911).1-2.

10 Ezek voltak a rovatok: I. Egyházi dolgozatok; II. Hittaniak, bölcselmiek; III. Nevelés- és oktatásügyiek; IV. Életiratok, történelmiek; V. Egyházi élet; VI. Vegyesek; VII. Irodalmi értesítő; VIII. Aranykönyv; IX. Különfélék (benne gyászhírek). 
A tanulmányi rovatban többévi kimaradás után újra rendszeresen jelentkezik Boros György. Borbély István a régi, unitárius vonatkozású, Kiss Ernő az újabb magyar irodalom kutatásával, Barabás Ábel világirodalmi dolgozataival tűnik ki. Szentmártoni Kálmán és Kelemen Lajos a történetírás képviselői. Csifó Salamon, Vári Albert, Benczédi Pál, Kiss Elek, György János, Győrffi István a teológiai-egyháztörténeti írások szerzői. Kauntzné Engel Ella a nőmozgalom kérdéseiről ír. E rovat címe 1914-ben kiegészül a „költemények”-kel is. Jékey Aladár, Barabás Ábel néhány versét közlik. Az utóbbinak 1915-ben a korai haláláról emlékeznek meg.

Az Irodalmi értesitő főleg az unitárius szerzők kisebb-nagyobb terjedelmű kiadványait ismerteti. Az iskolák értesítőit, a Dávid Ferenc-füzeteket ismerhetjük meg. Az Unitárius Szószék számairól is hírt kapunk, bemutatják a német háborús irodalmat.

A Különfélék az unitárius egyházi és tanügyi hírek mellett világegyházi, művelődési, politikai, sőt háborús eseményeknek is teret biztosítanak. Itt emlékeznek meg a halottakról, elesett katonákról. Olvashatunk a Titanic katasztrófájáról és a Balkán-háborúról, királykoronázásról és harangrekvirálásról vagy Kelemen Lajos levéltárosi kinevezéséről. 1917 végén a szerkesztők a nyomtatási költségek négyszeres növekedésére panaszkodnak, s kénytelenek az előfizetési árakat emelni ${ }^{11}$. 1918-ban pedig egy unitárius nyomda felállításában keresik a megoldást.

A világháború szerencsétlen kimenetele a folyóirat 1918. végi megszűnését vonja maga után. Az új politikai helyzetben az egyház hivatalos lapjaként az Unitárius Közlöny indul újra 1919 szeptemberében.

Az 1920 nyarán megalakult Unitárius Irodalmi Társaság 1922-től - mint saját folyóiratát - újraindította a Keresztény Magvetőt. Gálnak és Gálfinak is - legalább formailag - felajánlják a szerkesztői tisztséget, miután ők nem vállalják, a társaság főtitkára, Borbély István kezébe kerül a szerkesztés, aki maga mellé veszi Vári Albert vallástanárt.

Az új, 1922-es évfolyam első száma a két régi szerkesztő búcsúcikkével indul, többek között ezeket írják: „11 évvel ezelőtt, 1910 végén vettük át a visszavonuló szerkesztőtől a folyóirat »írói köre« megbízásából annak szerkesztését. Nagy kedvvel és nekilendüléssel fogtunk munkába. Régi programján nem sokat változtattunk. Szolgáltuk - tőlünk telhető erővel - a szabad kereszténység nagy céljait és a tiszta keresztény teizmus érdekeit. Megfelelő tért nyitottunk a nevelés elméleti és gyakorlati kérdései tárgyalásának. Azonban több volt a jóakarat részünkről, mint amennyi eredményt el tudtunk érni. Komolyan foglalkoztunk azzal a tervvel, hogy évi 6 füzet helyett 12 füzetet jelentessünk meg. [...] Folyóiratunk új államjogi helyzetben, tehát gyökeresen megváltozott új viszonyok között, meglehet, hogy új cél kitűzésével és erősebb, meggyarapodott eszközökkel folytatja életét. E korszakos fordulónál visszatekintve arra a nyolc esztendőre, amelyben a szerkesztőség élén álltunk, kedves kötelességünknek tartjuk hálás köszönetünket kifejezni annak a kis írói körnek, amely bizalommal kereste fel a folyóirat hasábjait tanulmányai közlésére és - anyagi jutalomra nem nézve - az ügy iránt való szeretetből oly készségesen támogattak, és az olvasóknak és előfizetőknek, akik áldozó lélekkel hozták el adójukat, s tették lehetővé, hogy folyóiratunkat nagyon szerény eszközökkel saját erején fenntarthassuk.

11 Olvasóinkhoz. Keresztény Magvető LII(1917). 249. 
Az Unitárius Irodalmi Társaság megalakulása után mi visszavonulunk. Az új szerkesztőknek kívánjuk, hogy azt a célt, melyet folyóiratunk félszáz év alatt nem sikertelenül munkált, ugyanolyan önzetlen lélekkel és buzgósággal, de sokkal nagyobb sikerrel és eredménnyel évek hosszú során át szolgálhassák!". ${ }^{12}$

A volt szerkesztők továbbra is közöltek a Magvetőben.

Gál Kelemen az 1920-as években, amikor a román törvények egyre jobban próbára tették a magyar tanügyi rendszert, az iskolaügy egyik legfelkészültebb szakemberévé vált. Az 1922 szeptemberében Sulyok István és Jakabffy Elemér összefogásával Lugoson megindított Magyar Kisebbség című havonta kétszer megjelenő „nemzetpolitikai szemle az erdélyi magyar nép számára”, már 1923-tól munkatársai közé számíthatta Gál Kelement. Évente egy-két, főleg a kisebbségi tanügy kálváriájára vonatkozó írással jelentkezett a kolozsvári kollégiumigazgató. A gondok a tanügy állandó reformálása során annyira felszaporodtak, hogy 1929ben már szükségessé vált egy külön melléklet indítása a folyóirat mellett csak a tanügyi témák tárgyalására, a törvények magyarázatára, esetleg lefordítására és az iskolákat, tanárokat érintő rendeletek, hírek közlésére. Feltételezzük, hogy a szerkesztőség kérte fel Gált a Kisebbségi Iskolaügy című melléklet összeállítására. Tény, hogy a fő laptestben, az 1929. július 16-i szám végén megjelent egy aláírás nélküli közlemény ${ }^{13}$, mely tudatja, hogy mellékletet indítanak, mely anyagi okokból nem válhat önálló folyóirattá. Célkitűzése kettős:

1. figyelemmel kísérni, magyarázni, bírálni a közoktatási kormány, tanfelügyelőségek rendeleteit;

2. „a jövő történetírója számára” összegyüjteni és kiadni azokat a rendeleteket, amelyek az iskolák életét meghatározzák. Nevelési-oktatási vitáknak egyelőre nem tudnak helyet adni.

E mellékletet másfél évig, 1929. július 16. és 1930. november 16. között egyedül Gál szerkesztette és írta. Összesen 9 számot állított össze. Számonként 16 lap terjedelműek. Az I. évfolyam így 52 lapra, a II. évfolyam pedig 96 lapra terjed. Minden szám elején egy-egy nagyobb, aláirt elemző tanulmányt közölt, s azután következtek az apró híradások tankönyvekről, tanítói-tanári vizsgákról, kedvezményekről, jóváhagyott szabályzatokról ${ }^{14}$.

A nagyobb tanulmányok sorra veszik az egyre újabb tanügyi törvényeket, s elemzik azokat, bevezetnek a román királyság iskolaügyének történetébe, s így érthetővé teszik az első világháborút követő fejleményeket.

Az apró híradásokból, rendeletekből érdemes tallózni. 1929-ben megtudjuk, hogy a kisebbségi tanárok román nyelvvizsgájára augusztus 15-31. között kijelölt vizsgaközpontokban kerül sor. Végre közölték, hogy Románia történetéből és földrajzából csak az ilyen szakos tanároknak kell külön vizsgát tenni. Miniszteri rendelet értelmében az elemikben csak egyetlen idegen nyelvet lehet tanítani, a magyar tannyelvüekben ez csak a román lehet. Az új tanév szeptember 16-án kezdődik. Eddig lehetett délelőtt és délután is tanítani, jövőtől csak dél-

12 A „Keresztény Magruetô” olvasóihoz I. Keresztény Magvető LIV(1922). 1-2.

13 Kisebbségi Iskolaügy. Magyar Kisebbség VIII(1929). 546-547.

14 A Magyar Kisebbség 1922-1942. (Repertórium. Törzsanyag. Személy- és helynevek analitikus mutatója. Osszeállította: Kazai Magdolna. Szeged, 1993.) címú kétkötetes munka nem tartalmazza a Kisebbségi Iskolaügy közleményeit. 
előtt, legtöbb 5 órát szabad tartani. A minisztérium két gazdasági tanintézetet (Herăstrăuban és Kolozsvárt) akadémiai rangra emelt, ezek 4 éves tanulmányi idő leteltével gazdamérnöki diplomát, valamint doktorátust is adhatnak. A testnevelő tanárok képzésére is két hároméves tanintézet létesül.

Az 1930-as híranyag tájékoztat például az engedélyezett három iskolai ünnepségről: nemzeti ünnep (május 10.), év végi ünnepély, az iskola patrónusának ünnepnapja. A „nemzeti tárgyakat" (román nyelv, Románia történelme, földrajza, jogi ismeretek) csak egyetemi licenciátussal és a pedagógiai szeminárium elvégzését igazoló vizsgával rendelkező tanár taníthat. A kisebbségi iskolák nyilvánossági jogának megvonása mindig a következő tanév kezdetén lép érvénybe. Líceumi felvételi vizsgán csak „saját” gyermekek vehetők fel: vagyis aki állami iskolába járt, nem jelentkezhetik felvételire felekezeti iskolába. Még kínosabb: a vizsgabizottság elnökét a minisztérium nevezi ki, akinek a napidíját és az útiköltségét rögtön ki kell fizetni. „Aztán egyáltalán olyan keleti íze van annak, hogy mikor a vizsgálat lejár, a kormány képviselője odaáll, s igényeit bejelentvén számadást csinál az igazgatóval. Ez a magyar világban soha sem volt, s inkább az állam érdeke kívánja, hogy itt is eltöröljék” - kommentálja Gál15. Jóváhagyták a középiskolai tanszemélyzet szabályzatát. Ez előírja a képesítés módozatait, a kinevezést, a tanári normát 15 órában szabja meg (20 évi szolgálat után csak 12-ben), intézkedik a továbbképzésről, nyelvvizsgáról. A nyugdíjazásra 65 éves korban kerül sor. „E1 kell ismernünk, hogy sok üdvös intézkedése van, s nagy haladást jelent a múlttal szemben" állapítja meg a szerkesztő ${ }^{16}$. Az üres tanszékek betöltésére vonatkozva figyelmeztet: ezután versenyvizsgát kell rendezni, s ez veszélyes, mert ha nincs magyar jelentkező, kénytelenek lesznek románt alkalmazni a magyar tannyelvü intézetek is.

A rövid életű „iskolapolitikai” melléklet minden magyar tanárnak, s fooleg iskolaigazgatónak igen hasznos munkaeszköz, tájékozódási forrás lehetett. Fenntartása, további szerkesztése valószínúleg anyagi okok miatt vált lehetetlenné. A nyugdíjba készülő Gál Kelemen sem tarthatta érdemesnek az állandóan változó rendeletek követését.

\section{KELEMEN GÁL, THE EDITOR}

\section{Keywords: Kelemen Gál, Kolozsvár, Unitarian College, Year-books, review Keresztény Magvetö}

Kelemen Gál (1869-1945) graduated the Unitarian College form Kolozsvár/Cluj, then he studied at the universities from Kolozsvár and Graz, he got specialized in German and Latin. He took his doctor's degree in Philosophy. He was a teacher of the most important Unitarian high-school from 1891 up to 1931, in the period 1900-1925 he was the head of the Unitarian College. Gál wrote studies in philosophy, philology, pedagogy, school and church history. It is important his activity as an editor. Being the head of the College, he was obliged to complete the year-books of the school. They contained all the important data referring to teachers, students, administration, as well an introductory study. These volumes were of 200-300 pages. Beginning with 1911 he became one of the editors of the oldest

15 Kisebbségi Iskolaügy 1930. 62-63.

16 Uo. 13-16. 
Unitarian review, “Keresztény Magvetô" (Christian Sawyer). Together with theology professor Lőrinc Gálfi they edited yearly 6 volumes of this theological-pedagogical-cultural review up to the end of 1918. Besides these, in 1929-1930 he edited a periodical with the title Kisebbségi Iskolaügy (Minority School-Affairs) which aimed to help the church-officials, teachers and school-directors to get informed about the Romanian laws and administrative measures concerning schools.

\section{KELEMEN GÁL, REDACTORUL}

\section{Cuvinte-cheie: Kelemen Gál, Cluj/Kolozsvár, Colegiul Unitarian, anuare, revista Keresz- tény Magvetö}

Kelemen Gál (1869-1945) a absolvit Colegiul Unitarian din Cluj, apoi a studiat la universităţile din Cluj şi Graz, specializându-se în germană şi latină. Şi-a luat doctoratul în filozofie. A lucrat ca profesor al celui mai important institut de învăţământ unitarian de la 1891 până în 1931, iar în perioada 19001925 a îndeplinit funcţia de director al acestui institut. Gál a scris studii de filozofie, filologie, pedagogie, precum şi de istoria bisericii şi ai şcolii. A avut şi o importantă activitate ca redactor. În calitatea sa de director a avut obligaţia să redacteze anuarele şcolare. Aceste anuare au cuprins toate datele importante despre profesori, elevi, administraţia şcolii precum şi un studiu introductiv. Volumele anuarului au fost de 200-300 de pagini. Incepând cu 1911 a devenit unul dintre cei doi editori ai revistei unitariene „Keresztény Magvető” (Semănătorul Creştin). Împreună cu profesorul de teologie Lőrinc Gálfi au redactat anual şase numere al acestei reviste de teologie-pedagogie şi de cultură până în 1918. În afară de aceste periodice în 1929-1930 Gál a mai redactat şi un supliment de revistă întitulat Kisebbségi Iskolaügy (Problemele Şcolilor Minoritare) care a avut ca scop informarea funcţionarilor bisericeşti, a profesorilor şi al directorilor de şcoli despre legile şi măsurile administrative din România legate de viaţa şcolilor. 